\title{
PENGARUH PENGALAMAN KEUANGAN DAN TINGKAT PENDAPATAN TERHADAP PERILAKU KEUANGAN KELUARGA DI DESA YOSOWILANGUN KECAMATAN MANYAR GRESIK
}

\author{
Wasti Reviandani \\ reviandaniwasti@gmail.com \\ Progam Studi Manajemen Fakultas Ekonomi dan Bisnis \\ Universitas Muhammadiyah Gresik
}

\begin{abstract}
This study analyzes the effect of financial experience and income level on family financial behavior. This research took place in Yosowingaun village in Manyar Gresik sub-district, which was inhabited by 9490 residents with economic activities including trading, farming, or being employees. The samples taken from this study were 38 people using multiple linear regression analysis, the results of this study that Financial experience and the level of opinion of citizens significantly influence family financial behavior in Yosowilangun village, Manyar Gresik sub-district.
\end{abstract}

Keywords: Financial experience, income level, financial behavior

\section{PENDAHULUAN}

Saat ini kebutuhan dan keinginan tiap manusia semakin tinggi, sehingga manusia seharusnya memiliki pengetahuan keuangan. Pada kelompok terkecil dalam masyarakat yaitu keluarga perlu untuk menerapkan pengelolaan keuangan yang baik agar bisa mengelola dan mengambil keputusan keuangan dengan tepat. Merujuk dari Perry dan Moris (2005) bahwa Keluarga yang sudah dapat bertanggung jawab atas uang yang dimiliki, mengelola anggaran serta mengontrol pengeluaran adalah keluarga yang dapat mengelola keuangan dengan benar dan tepat

Financial management behavior yang efektif melibatkan literasi keuangan yang baik, literasi keuangan secara sedaerhana adalah kondisi seseorang yang memiliki pengetahuan dan pemahaman tentang keuangan. Robb dan Woodyard (2011) mengemukakan bahwa literasi keuangan yang cukup dapat memberikan pengaruh positif kepada perilaku keuangan seseorang, seperti mengatur serta mengalokasikan keuangannya secara tepat. Dalam survey yang dilakkukan oleh Bank Dunia tahun 2014 menunjukkan bahwa tingkat literasi keuangan Indonesia hanya 20\%. Hal ini lebih rendah dibanding negara ASEAN lainnya seperti Filipina 27\%, Malaysia 66\%, Thailand $73 \%$ dan Singapura $98 \%$. Oleh karena itu sangat dibutuhkan pengetahuan keuangan dalam meningkatkan perekonomian.

Literasi keuangan dalam keluarga yang kurang membuat banyak keluarga belum menyadari pentingnya mempunyai manajemen keuangan dalam kehidupan pribadinya. Menurut Hilgret \& Jeanne dalam yulianti dan Sivy (2013) menyatakan bahwa keputusan keuangan yang baik dan benar dibutuhkan untuk meningkatkan pendapatan, mengelola pengeluaran, pembayaran pajak agar manajemen keuangan keluarga menjadi baik. Pengalaman masa kecil yang positif mengenai mengelola keuangan, lingkungan sosial maupun sikap 
terhadap penghematan memainkan peranan penting manajemen keuangan dalam perilaku keluarga pada masa yang akan datang. Didalam keluarga sikap keuangan dapat mempengaruhi kondisi keuangan dalam menjalani kehidupannya, jika keluarga tidak mampu mengambil sikap, selain pengalaman keuangan yang harus diperhatikan adalah tingkat pendapatan keluarga tersebut. Menurut Yulianti dan Sivy (2013) tingkat pendapatan keluarga menentukan tingkatan social dan demografis yang nantinya setiap tingkatan tersebut mempunyai perilaku keuangan yang berbeda-beda bedasarkan konsumsi mereka.

Perekonomian Gresik banyak ditunjang dari sektor industri dan perikanan yang signifikan, ada beberapa industri di Gresik seperti Semen Gresik, Petrokimia Gresik, BHS-Tex, Nippon Paint, Industri perkayuan dan Maspion. Sehingga, sebagian besar penduduk kabupaten Gresik mempunyai mata pencaharian sebagai buruh, yang secara pendidikan rata-rata menengah, hal ini juga akan membentuk pola perilaku manajemen keuangan yang berbeda-beda dari daerah lain.

Dari latar belakang disimpulkan bahwa isu perilaku pengelolaan keuangan penting di era milenial ini, sehingga penulis bertujuan untuk menguji pengaruh pengalaman keuangan dan tingkat pendapatan terhadap perilaku keuangan keluarga di Desa Yosowilangun kecamatan Manyar Gresik.

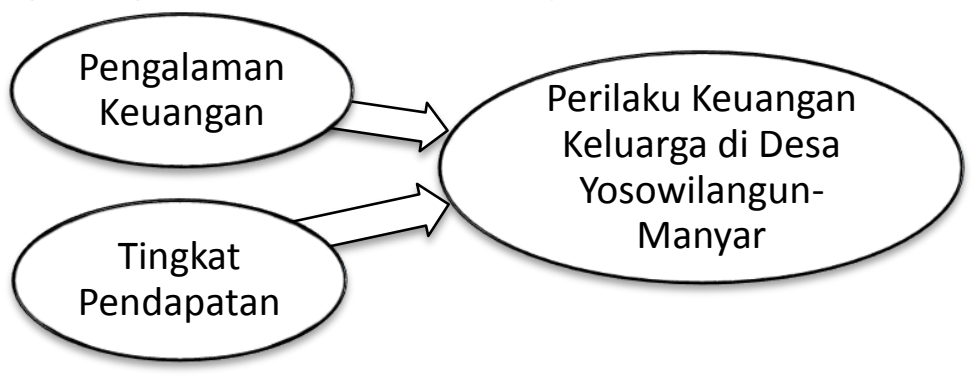

\section{Hipotesis}

Hipotesis dalam penelitian ini adalah sebagai berikut:

H1: Pengalaman Keuangan berpengaruh signifikan terhadap perilaku keuangan keluarga di Desa Yosowilangun Kecamatan Manyar.

H2: Tingkat Pendapatan berpengaruh signifikan terhadap perilaku keuangan keluarga di Desa Yosowilangun Kecamatan Manyar.

\section{METODE PENELITIAN}

Penelitian ini menggunakan data primer berupa interview dan mendistribusikan kuisioner kepada para responden. Jenis variabel penelitian meliputi pengalaman keuangan, tingkat pendapatan, dan perilaku keuangan. Penelitian ini menggunakan data yang diperoleh dari responden atau kepala keluarga, Penelitan ini menggunakan data Primer yaitu data yang dikumpulkan dari penyebaran kuisioner kepada kepala keluarga yang sudah dibuat dan disusun dalam bentuk pertanyaan. Populasi penelitian ini yaitu kepala keluarga di desa Yosowilangun kecamatan Manyar Gresik. Dalam penelitian ini teknik penentuan sampel yakni dengan menggunakan simple random sampling. sampel dalam penelitian ini sebanyak 38 kepala keluarga di desa Yosowilangun kecamatan Manyar Gresik. 


\section{Variabel Penelitian}

Variabel-variabel dalam penelitian ini dapat diidentifikasikan menjadi dua yaitu independent variabel dan dependent variabel

1. Variabel bebas (independent variabel), dalam penelitian ini adalah pengalaman keuangan (X1), tingkat pendapatan (X2)

2. Variabel terikat (dependent variabel), yang menjadi variabel terikat dalam penelitian ini adalah perilaku keuangan $(\mathrm{Y})$.

\section{Teknik Pengukuran Variabel}

Pengukuran variabel berdasarkan dari tanggapan responden terhadap setiap indikator menggunakan range 1 sampai 5 dengan skala Likert. Uji validitas dan reliabilitas dengan menggunakan metode statistika didukung perangkat lunak komputer/software yaitu menggunakan program SPSS (Statistic Program for Social System) versi 17.0.

\section{Analisis Data}

Metode analisis data yang digunakan penelitian ini adalah analisis regresi linier berganda (Multiple Linear Regression Analysis) digunakan untuk meregresikan secara simultan antara variabel bebas (independent variable) yaitu pengalaman keuangan $\left(X_{1}\right)$ dan tingkat pendapatan $\left(\mathrm{X}_{2}\right)$ dengan variabel terikat (dependent variable) yaitu perilaku keuangan (Y).

\section{Koefisien Determinasi Berganda}

Nilai yang mendekati satu (1) berarti variabel-variabel bebas memberikan hampir semua informasi yang dibutuhkan untuk memprediksi variasi variabel terikat. Sebaliknya diperoleh hasil semakin kecil atau mendekati nol (0), maka sumbangan variabel independen terhadap variabel dependen semakin kecil.

\section{HASIL DAN PEMBAHASAN} Variabel Pengalaman keuangan

Variabel pengalaman keuangan, responden memberi jawaban tertinggi untuk indikator riwayat pendidikan terakhir dengan rata-rata sebesar 3,94. Sedangkan responden memberi jawaban terendah untuk indikator perencanaan pengeluaran dengan ratarata sebesar 3,52. Rata-rata variabel pengalaman keuangan sebesar 3,75, hal ini menunjukkan bahwa pengalaman keuangan tinggi dirasakan responden.

\section{Variabel Tingkat pendapatan}

variabel tingkat pendapatan, responden memberi jawaban tertinggi untuk indikator pemasukan tambahan dengan skor rata-rata sebesar 3,44. Sedangkan responden memberi jawaban terendah untuk indikator investasi dengan skor rata-rata sebesar 3,34. Rata-rata variabel tingkat pendapatan sebesar 3,42 . Secara keseluruhan diketahui tingkat pendapatan dinilai sedang oleh karyawan, ditunjukkan nilai rata-rata jawaban responden sebesar 3,42.

\section{Variabel Perilaku keuangan}

variabel perilaku keuangan, responden memberikan jawaban tertinggi untuk indikator prioritas belanja dengan skor rata-rata sebesar 4.47. Sedangkan responden memberikan jawaban terendah untuk indikator keuangan jangka pendek output yang sesuai dengan skor rata-rata sebesar 3.73. Rata-rata variabel perilaku keuangan sebesar 4.03. Secara keseluruhan diketahui bahwa perilaku keuangan dinilai tinggi oleh responden.

\section{Pengujian Validitas dan Reliabilitas Uji Validitas}

Berikut adalah hasil pengujian validitas untuk masing-masing item pernyataan pada variabel pengalaman keuangan: 
Tabel Pengujian Validitas Pada Variabel Pengalaman keuangan

\begin{tabular}{|l|c|c|c|}
\hline \multicolumn{1}{|c|}{ Indikator } & $\begin{array}{c}\text { Koefisien Korelasi } \\
\text { Pearson }\end{array}$ & Nilai r tabel & Keterangan \\
\hline Riwayat pendidikan terakhir & 0,770 & 0,320 & Valid \\
\hline Kegiatan menabung & 0,818 & 0,320 & Valid \\
\hline Merencanakan pengeluaran & 0,855 & 0,320 & Valid \\
\hline $\begin{array}{l}\text { Faktor-faktor anggaran } \\
\text { keuangan }\end{array}$ & 0,722 & 0,320 & Valid \\
\hline
\end{tabular}

Sumber : Output SPSS, 2019

Berdasarkan tabel diketahui nilai koefisien korelasi pearson $\left(\mathrm{r}_{\text {hitung }}\right.$ ) pada setiap item pernyataan variabel pengalaman keuangan lebih besar dari nilai $\mathrm{r}$ tabel $=0,320$, maka dapat disimpulkan setiap item pernyataan untuk mengukur variabel pengalaman keuangan dapat dikatakan valid dan dapat digunakan pada analisis selanjutnya.

Berikut adalah hasil pengujian validitas untuk masing-masing item pernyataan pada variabel tingkat pendapatan:

Tabel Pengujian Validitas Pada Variabel Tingkat pendapatan

\begin{tabular}{|l|c|c|c|}
\hline \multicolumn{1}{|c|}{ Indikator } & Koefisien Korelasi Pearson & Nilai $r$ tabel & Keterangan \\
\hline Pemasukan gaji rutin & 0,771 & 0,320 & Valid \\
\hline Bonus dan insentif & 0,788 & 0,320 & Valid \\
\hline Pemasukan tambahan & 0,587 & 0,320 & Valid \\
\hline Investasi & 0,851 & 0,320 & Valid \\
\hline
\end{tabular}

Sumber : Output SPSS, 2019

Berdasarkan tabel 4.12 diketahui nilai koefisien korelasi pearson $\left(\mathrm{r}_{\text {hitung }}\right.$ ) pada masing-masing item pernyataan variabel tingkat pendapatan lebih besar dari nilai $\mathrm{r}$ tabel $=0,320$, dengan demikian dapat disimpulkan masingmasing item pernyataan untuk

mengukur variabel tingkat pendapatan dapat dikatakan valid dan dapat digunakan pada analisis selanjutnya.

Berikut adalah hasil pengujian validitas untuk masing-masing item pernyataan pada variabel perilaku keuangan:

Tabel Pengujian Validitas Pada Variabel Perilaku keuangan

\begin{tabular}{|l|c|c|c|}
\hline \multicolumn{1}{|c|}{ Indikator } & $\begin{array}{c}\text { Koefisien Korelasi } \\
\text { Pearson }\end{array}$ & $\begin{array}{c}\text { Nilai } \mathrm{r} \\
\text { table }\end{array}$ & Keterangan \\
\hline Kunatitas Output $\left(\mathrm{Y}_{1}\right)$ & 0,770 & 0,320 & Valid \\
\hline Kualitas Output $\left(\mathrm{Y}_{2}\right)$ & 0,877 & 0,320 & Valid \\
\hline Jangka Waktu Output $\left(\mathrm{Y}_{3}\right)$ & 0,779 & 0,320 & Valid \\
\hline Tingkat Absensi $\left(\mathrm{Y}_{4}\right)$ & 0,543 & 0,320 & Valid \\
\hline
\end{tabular}

Sumber : Output SPSS, 2019

Berdasarkan tabel diketahui nilai koefisien korelasi pearson $\left(\mathrm{r}_{\text {hitung }}\right.$ ) pada masing-masing item pernyataan variabel perilaku keuangan lebih besar dari nilai $\mathrm{r}$ tabel $=0,320$, dengan demikian dapat disimpulkan masing- masing item pernyataan untuk mengukur variabel perilaku keuangan dapat dikatakan valid dan dapat digunakan pada analisis selanjutnya.

\section{Uji Reliabilitas}


Tabel Hasil Uji Reliabilitas Masing-masing Variabel

\begin{tabular}{|l|c|c|c|}
\hline \multicolumn{1}{|c|}{ Variabel } & Cronbach Alpha & Nilai kritis & Keterangan \\
\hline Pengalaman keuangan(X1) & 0,940 & 0,60 & Reliabel \\
\hline Tingkat pendapatan(X2) & 0,940 & 0,60 & Reliabel \\
\hline Perilaku keuangan (Y) & 0,939 & 0,60 & Reliabel \\
\hline
\end{tabular}

Sumber : Output SPSS, 2019

Pada table diatas diketahui bahwa besarnya nilai cronbach alpha di tiap variabel pengalaman keuangan, tingkat pendapatandan perilaku keuangan lebih besar dari nilai kritis 0,6. Maka dapat disimpulkan bahwa variabel pengalaman keuangan, tingkat pendapatandan perilaku keuangan

adalah reliabel/konsisten dan dapat digunakan pada analisis selanjutnya.

\section{Pengujian Analisis Statistik}

\section{Uji Normalitas}

Hasil dari uji normalitas pada penelitian ini dapat dilihat dari dua grafik berikut ini:

\section{Gambar Grafik Uji Normalitas}

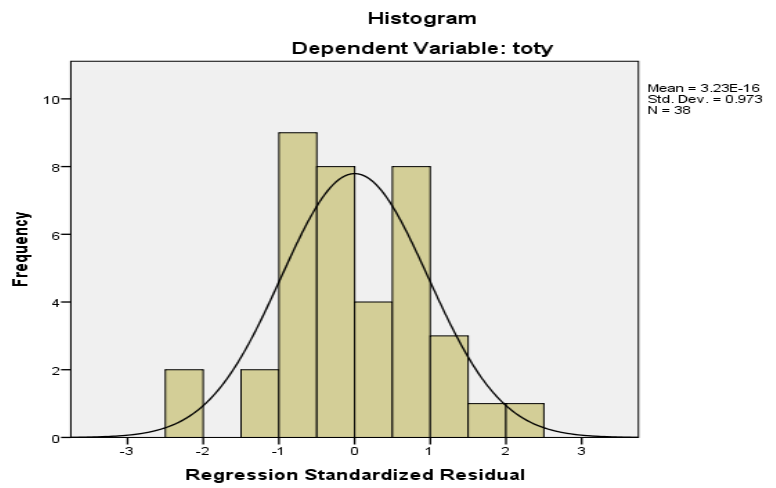

Sumber : Output SPSS, 2019

Data dikatakan berdistribusi membentuk kurva yang mendekati normal apabila kurva yang ada pada berbentuk lonceng. Maka dapat grafik membentuk bel (lonceng). Pada disimpulkan data berdistribusi normal. grafik diatas dapat dilihat sebaran data

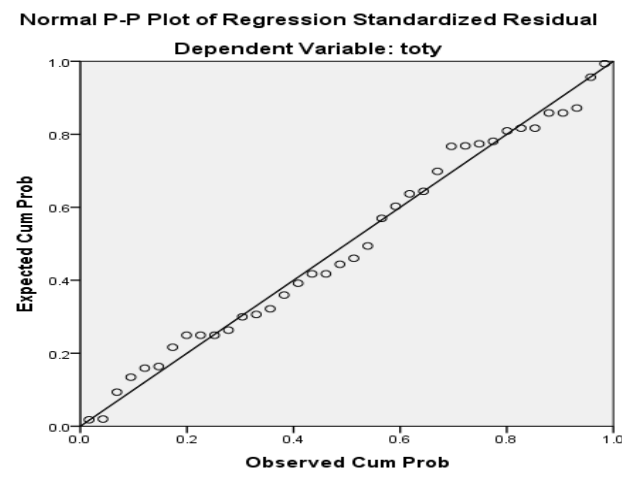

Deteksi normalitas dapat dilihat dari penyebaran data (titik) di sumbu diagonal pada grafik. Jika data menyebar disekitar dan mendekati garis diagonal ataupun mengikuti arah garis diagonal, maka model regresi tersebut memenuhi asumsi normalitas. Pada gambar grafik di atas dapat dilihat bahwa data menyebar disekitar dan mendekati garis diagonal, dan mengikuti arah dari garis diagonal, sehingga dapat dikatakan model regresi telah memenuhi asumsi normalitas sehingga layak digunakan untuk analisis selanjutnya. 
Tabel Hasil Uji Multikolinieritas

One-Sample Kolmogorov-Smirnov Test

\begin{tabular}{|ll|r|r|r|}
\hline & & \multicolumn{1}{c|}{ totx1 } & \multicolumn{1}{c|}{ totx2 } & \multicolumn{1}{c|}{ Toty } \\
\hline $\mathrm{N}$ & Mean & 38 & 38 & 38 \\
Normal Parameters ${ }^{\mathrm{a}, \mathrm{b}}$ & Std. & .7500 & 3.4276 & 4.0329 \\
& Deviation & .65502 & .64438 & .63184 \\
& Absolute & .149 & .150 & .190 \\
& .115 & .113 & .152 \\
Most Extreme Differences & Positive &. .149 & -.150 & -.190 \\
& Negative & .916 & .924 & 1.170 \\
Kolmogorov-Smirnov Z & & .371 & .360 & .130 \\
Asymp. Sig. (2-tailed) & & \multicolumn{3}{|c}{} \\
\hline
\end{tabular}

a. Test distribution is Normal.

b. Calculated from data.

Sumber : Output SPSS, 2019

Pada tabel diketahui bahwa nilai

K-S pengalaman keuangan adalah 0.916 dengan probabilitas 0,371, tingkat pendapatan0.924 dengan probabilitas 0,360 , dan perilaku keuangan 1,170 dengan probabilitas 0,130 (Asymp.Sig (2-tailed). Persyaratan data disebut normal pada uji normalitas dengan K-S. Oleh karena itu nilai $\mathrm{p}$ semua variabel > 0,05 , maka diketahui bahwa residual berdistribusi normal.

\section{Multikolinieritas}

Hasil dari uji multikolinieritas dapat dianalisis dari tabel berikut : apabila nilai probabilitas atau $\mathrm{p}>0,05$

Tabel Hasil Uji Multikolinieritas

Coefficients $^{\mathrm{a}}$

\begin{tabular}{|ll|r|r|}
\hline \multirow{2}{*}{ Model } & \multicolumn{3}{|c|}{ Collinearity Statistics } \\
\cline { 2 - 4 } & Tolerance & \multicolumn{1}{c|}{ VIF } \\
\hline 1 & $\begin{array}{l}\text { Pengalaman } \\
\text { keuangan(X1) } \\
\text { Tingkat } \\
\text { pendapatan(X2) }\end{array}$ & .280 & 3.851 \\
\hline
\end{tabular}

a. Dependent Variable: Perilaku keuangan (Y)

Suatu model regresi yang bebas multikolinieritas adalah yang mempunyai nilai VIF lebih dari 1 tetapi kurang dari 10 dan mempunyai angka Tolerance mendekati 1. Pada tabel coefficients diatas dapat diketahui nilai VIF dari variabel independen pengalaman keuangandan tingkat pendapatanberada di angka lebih dari 1 tetapi kurang dari 10, sedangkan nilai Tolerance dari dua variabel independen tersebut mendekati 1 .
Berdasarkan hal tersebut dapat disimpulan model regresi pada penelitian ini bebas dari problem multikolinieritas. Selain itu, suatu model regresi yang bebas multikolinieritas adalah semua variabel independennya tidak berhubungan erat satu sama lain. Koefisien korelasi antar variabel independen harus lemah (di bawah 0,5). Jika korelasi kuat maka terjadi problem multikolinieritas. 
Berdasarkan hal tersebut dapat diambil kesimpulan bahwa penelitian ini tidak ada multikolinieritas antar variabel independen, sehingga layak digunakan untuk analisis selanjutnya.

\section{Uji Heteroskedastisitas}

Jika variabel independen hasilnya signifikan secara statistik mempengaruhi variabel independen dibawah $0,05(<0,05)$, maka terjadi heteroskedastisitas. Jika tidak ada satupun variabel independen yang signifikan secara statistik mempengaruhi variabel independen diatas $0,05(>0,05)$, maka tidak terjadi heteroskedastisitas. Model regresi yang baik (normal) adalah model yang homoskedastis. diketahui bahwa tidak ada variabel independen yang hasilnya signifikan mempengaruhi variabel dependen, hal ini dilihat dari probabilitas signifikansinya $\mathrm{di}$ atas $\mathbf{1}$ 0,05. Jadi dapat disimpulkan bahwa model tidak terjadi heterokedastisitas

\section{Uji Linieritas}

Uji linieritas ini bertujuan untuk mengetahui apakah bentuk pengaruh antara variabel bebas dengan variabel terikat linier. Uji linieritas yang dipakai dalam perhitungan ini meggunakan uji $\mathrm{F}$ melalui rumus ANOVA. Uji linieritas yang dilakukan pada variabel pengalaman keuangan $\left(\mathrm{X}_{1}\right)$ dan variabel tingkat pendapatan $\left(\mathrm{X}_{2}\right)$ dan perilaku keuangan (Y) menunjukkan nilai signifikasi dibawah $0,05(<0,05)$, sehingga bisa dikatakan bahwa garis regresi bersifat linier.

diketahui bahwa bahwa angka linearity dibawah $0,05 \quad(<0,05)$, berarti hubungan antara variabel dependen dengan variabel independen adalah linear. Dengan demikian dapat disimpulkan bahwa model persamaan regresi linier dalam penelitian ini, bebas dari asumsi dasar klasik tersebut.

1. Analisis Regresi Linier Berganda

Tabel Koefisien Regresi Linier Berganda

Coefficients $^{\mathrm{a}}$

\begin{tabular}{|c|c|c|c|c|c|c|}
\hline \multirow{2}{*}{\multicolumn{2}{|c|}{ Model }} & \multicolumn{2}{|c|}{$\begin{array}{c}\text { Unstandardized } \\
\text { Coefficients }\end{array}$} & \multirow{2}{*}{$\begin{array}{c}\text { Standardized } \\
\text { Coefficients }\end{array}$} & \multirow[b]{2}{*}{$\mathrm{t}$} & \multirow[b]{2}{*}{ Sig. } \\
\hline & & B & Std. Error & & & \\
\hline \multirow[t]{3}{*}{1} & (Constant) & .766 & .275 & & 2.781 & .009 \\
\hline & $\begin{array}{l}\text { Pengalaman } \\
\text { keuangan }(\mathrm{X} 1)\end{array}$ & .535 & .141 & .555 & 3.803 & .001 \\
\hline & $\begin{array}{l}\text { Tingkat } \\
\text { pendapatan }(\mathrm{X} 2)\end{array}$ & .368 & .143 & .375 & 2.569 & .015 \\
\hline
\end{tabular}

a. Dependent Variable: Perilaku keuangan (Y)

Sumber:Output SPSS, 2019

1. Koefisien regresi sebesar 0,766 menyatakan bahwa jika tidak ada variabel pengalaman keuangandan tingkat pendapatan, maka perilaku keuangan adalah sebesar 0,766 .

2. Koefisien regresi $X_{1}$ sebesar 0,535 menyatakan bahwa setiap penambahan variabel pengalaman keuangan, maka perilaku keuangan akan meningkat sebesar 0,535.

3. Koefisien regresi $X_{2}$ sebesar 0,368 menyatakan bahwa setiap penambahan variabel tingkat pendapatan, maka perilaku keuangan akan meningkat sebesar 0,368 . 
Koefisien Determinasi Berganda $\left(\mathbf{R}^{2}\right)$

Model Summary ${ }^{\mathrm{b}}$

Tabel Koefisien Determinasi Berganda

\begin{tabular}{|c|c|c|c|c|c|}
\hline Model & $\mathrm{R}$ & R Square & $\begin{array}{c}\text { Adjusted R } \\
\text { Square }\end{array}$ & $\begin{array}{c}\text { Std. Error of the } \\
\text { Estimate }\end{array}$ & $\begin{array}{c}\text { Durbin- } \\
\text { Watson }\end{array}$ \\
\hline 1 & $.898^{\mathrm{a}}$ & .807 & .795 & .28577 & 1.438 \\
\hline
\end{tabular}

a. Predictors:(Constant), Tingkat pendapatan(X2), Pengalaman keuangan(X1)

b. Dependent Variable: Perilaku keuangan (Y)

Sumber : Output SPSS, 2019

Hasil perhitungan koefisien determinasi berganda $\left(\mathrm{R}^{2}\right)$ dapat dilihat dari tabel diatas:

1. Pada tabel di atas didapat angka $\mathrm{R}$ sebesar 0,898 $(>0,5)$ menunjukkan bahwa korelasi antara variabel dependen perilaku keuangan dengan dua variabel independen yaitu pengalaman keuangan dan tingkat pendapatan sangat kuat.

2. Angka $\mathrm{R}$ square atau koefisien determinasi adalah 0,807. Namun dalam penelitian ini digunakan angka Adjusted $R$ Square karena jika jumlah variabel pada penelitian ini lebih dari dua, lebih baik digunakan adalah Adjusted $R$ Square. Angka Adjusted R Square adalah 0,807 hal ini berarti 80,7\% variasi dari variabel perilaku keuangan dapat dijelaskan oleh variabel pengalaman keuangan dan tingkat pendapatan, sedangkan sisanya sebesar $19.3 \%$ dijelaskan oleh variabel-variabel lain.

\section{Uji t (Uji Parsial)}

Coefficients $^{\mathrm{a}}$

\begin{tabular}{|c|c|c|c|c|c|}
\hline \multirow[b]{2}{*}{ Model } & \multicolumn{2}{|c|}{$\begin{array}{c}\text { Unstandardized } \\
\text { Coefficients } \\
\end{array}$} & \multirow{2}{*}{$\begin{array}{c}\text { Standardized } \\
\text { Coefficients }\end{array}$} & \multirow[b]{2}{*}{$\mathrm{T}$} & \multirow[b]{2}{*}{ Sig. } \\
\hline & B & Std. Error & & & \\
\hline $1 \quad$ (Constant) & .766 & .275 & & 2.781 & .009 \\
\hline $\begin{array}{l}\text { Pengalaman } \\
\text { keuangan }(X 1)\end{array}$ & .535 & .141 & .555 & 3.803 & .001 \\
\hline $\begin{array}{l}\text { Tingkat } \\
\text { pendapatan }(\mathrm{X} 2)\end{array}$ & .368 & .143 & .375 & 2.569 & .015 \\
\hline
\end{tabular}

a. Dependent Variable: Perilaku keuangan (Y)

Sumber : Output SPSS, 2019

Berdasarkan pada tabel di atas ditarik beberapa kesimpulan sebagai berikut:

1. Nilai $t_{\text {hitung }}$ variabel Pengalaman keuangan $\left(\mathrm{X}_{1}\right)$ sebesar 3,803 pada taraf signifikansi di bawah 5\% yaitu sebesar 0,00. Berdasarkan probabilitas, disimpulkan bahwa variabel pengalaman keuangan $\left(\mathrm{X}_{1}\right)$ mempunyai pengaruh signifikan pada variabel perilaku keuangan (Y)
2. Nilai thitung variabel Tingkat pendapatan $\left(\mathrm{X}_{2}\right)$ adalah sebesar 2.569 pada taraf signifikansi di bawah 5\% yaitu sebesar 0,015. Berdasarkan probabilitasnya, dapat disimpulkan bahwa variabel tingkat pendapatan $\left(\mathrm{X}_{2}\right)$ memiliki pengaruh signifikan terhadap variabel perilaku keuangan $(\mathrm{Y})$. 


\section{Uji F (Uji Simultan)}

\section{Tabel Hasil Uji F}

ANOVA $^{b}$

\begin{tabular}{|rl|r|r|r|c|c|}
\hline Model & & Sum of Squares & Df & Mean Square & F & Sig. \\
\hline 1 & Regression & 11.913 & 2 & 5.957 & 72.940 & $.000^{\mathrm{b}}$ \\
& Residual & 2.858 & 35 & .082 & & \\
& Total & 14.771 & 37 & & & \\
\hline
\end{tabular}

a. Predictors:(Constant), Tingkat pendapatan(X2), Pengalaman keuangan(X1)

b. Dependent Variable: Perilaku keuangan (Y)

Sumber : Output SPSS, 2019

Pengujian hipotesis regresi secara bersama-sama (uji F) ditunjukkan untuk mengetahui pengaruh kedua variabel bebas secara simultan terhadap variabel terikat dalam suatu model. Kriteria uji F ini adalah:

1. Jika hasil statistik $F$ pada taraf signifikan alpha $=5 \%$ diperoleh nilai signifikansi $F>0,05$, berarti variabel-variabel bebas secara simultan mempunyai pengaruh yang tidak signifikan terhadap variabel terikat.

2. Jika hasil statistik $\mathrm{F}$ pada taraf signifikan alpha $=5 \%$ diperoleh nilai signifikansi $\mathrm{F}<0,05$, berarti variabel bebas secara simultan mempunyai pengaruh yang signifikan terhadap variabel terikat.

3. Pada tabel 4.23, dapat diketahui bahwa nilai $\mathrm{F}$ hitung hasil regresi adalah sebesar 72.940 dengan tingkat signifikansi 0,00 sehingga terdapat pengaruh yang signifikan secara simultan variabel independen pengalaman keuangan $\left(\mathrm{X}_{1}\right)$ dan tingkat pendapatan $\left(\mathrm{X}_{2}\right)$ terhadap variabel dependen perilaku keuangan (Y). Dengan demikian sesuai dengan hipotesis yang menyatakan "diduga pengalaman keuangandan tingkat pendapatan berpengaruh secara simultan dan signifikan terhadap perilaku keuangan" diterima kebenarannya.
Berikut akan dibahas temuan penelitian atas analisis data empiris sehubungan dengan hipotesis yang diajukan yaitu pengaruh pengalaman keuangan dan tingkat pendapatan terhadap perilaku keuangan.

\section{Pengaruh Pengalaman keuangan Terhadap Perilaku keuangan}

Pengaruh pengalaman keuangan didalam penelitian ini terdiri dari empat indikator yaitu, pendidikan, kegiatan menabung, merencakanan pengeluaaran, factor-faktor anggaran keuangan. Berdasarkan distribusi jawaban responden didapatkan indikator tertinggi riwayat pendidikan terakhir dengan skor rata-rata sebesar 3,94. Dengan demikian dapat dikatakan bahwa indikator riwayat pendidikan lebih kuat dalam membentuk variabel motivasi ekstrisik dibandingkan dengan indikator lainnya. Hal ini dikarenakan semakin tinggi tingkat pendidikan responden maka perencanaan keuangan lebih terstruktur. Hal ini di dukung oleh ilmu-ilmu ilmiah dan social yang didapat dalam proses pendidikan.

Pengalaman

keuangan merupakan kemampuan seseorang dalam mempertimbangkan dan mengambil keputusan investasi yang didasari oleh pengalaman masa kecil, lingkungan social, sikap terhadap penghematan dll maka tentunya 
pengalaman keuangan ini dapat mempengaruhi seseorang dalam perilaku keuangan ketika telah berumah tangga.

Berdasarkan perhitungan pada analisis statistik di atas, pengalaman keuangan mempunyai pengaruh positif terhadap perilaku keuangan keluarga Hasil dari penelitian ini didukung dengan hasil penelitian Mudjiyati (2016) bahwa pengalaman keuangan mempunyai pengaruh signifikan dengan perilaku keuangan.

\section{Pengaruh Tingkat pendapatan Terhadap Perilaku keuangan}

Pengaruh tingkat pendapatan didalam penelitian ini terdiri dari empat indikator yaitu pemasukan gaji rutin, bonus dan insentif, pemasukan tambahan, investasi. Berdasarkan distribusi jawaban responden tertinggi untuk indikator Pemasukan gaji rutin dengan skor rata-rata sebesar 3,44. Hal ini menunjukkan rata-rata responden setuju atas indikator pemasukan gaji ruti sebagai tingkat pendapatan yang bisa diukur secara pasti.

Berdasarkan perhitungan pada analisis statistik di atas, tingkat pendapatan mempunyai pengaruh positif terhadap perilaku keuangan. Hal ini dapat diartikan, jika tingkat pendapatan meningkat maka perilaku keuangan responden akan mengalami peningkatan.

Hasil analisis statistik di atas mendukung hasil penelitian Mudjiyati (2016) yang mengemukakan bahwa adanya pengaruh positif dan signifikan antara tingkat pendapatan terhadap perilaku keuangan.

Pengaruh

keuangandan

pendapatanTerhadap

Pengalaman

Tingkat

Perilaku

keuangan Pengaruh pengalaman keuangandan tingkat pendapatan secara simultan memiliki pengaruh positif terhadap perilaku keuangan. Hal ini dapat diartikan, jika pengalaman keuangan tinggi dan pegawai mempunyai tingkat pendapatan yang baik, maka perilaku keuangan responden akan mengalami peningkatan.

Hasil dari penelitian ini didukung dengan hasil penelitian Mudjiyati (2016), Nabila (2016) dan Yulianti Silvy (2013) menunjukkan pengalaman keuangan dan tingkat pendapatan secara simultan bersamasama berpengaruh terhadap perilaku keuangan.

\section{SIMPULAN DAN SARAN \\ Simpulan}

Hasil analisis data dan pembahasan diambil kesimpulan sebagai berikut :

1. Pengalaman keuangan mempunyai pengaruh yang positif dan signifikan terhadap perilaku keluarga di desa Yosowilangun kecamatan Manyar Gresik

2. Tingkat pendapatan mempunyai pengaruh yang positif dan signifikan terhadap perilaku keuangan keluarga di desa Yosowilangun kecamatan Manyar Gresik

3. Pengalaman keuangan dan tingkat pendapatan secara bersama-sama mempunyai pengaruh yang positif dan signifikan terhadap perilaku keuangan keluarga di desa Yosowilangun kecamatan Manyar Gresik.

\section{Saran}

1. Dalam mengimplementasikan pengalaman keuangan responden disarankan meningkatkan kemampuan dalam merencakan dan mengelola keuangan keluarga dengan memperhatikan sifat-sifat kebutuhan rutin, kebutuhan prioritas dll.

2. Dalam mengiplementasikan tingkat pendapatan responden disarankan 
merencanakan usaha-usaha bisnis sampingan sehingga bisa menambah tingkat pendapatan.

3. Bagi peneliti selanjutnya, penelitian ini juga dapat dilakukan di kondisi daerah yang mempunyai perbedaan etnologi misalnya, perkotaan dan peneliti selanjutnya dapat menambahkan/memodifikasi indikator yang peneliti gunakan pada saat ini, serta menambahkan atau mengganti variabel dependen lain.

\section{DAFTAR PUSTAKA}

Nabilla, Rahmawati. 2016. Pengaruh Pengetahuan Keuangan, Pendapatan Dan Gaya Hidup Terhadap Perilaku Pengelolaan Keuangan Profesional Muda Di Surabaya. Jurnal STIE PERBANAS SURABAYA

Purwidianti dan Mudjiyanti. 2016. Analisis Pengaruh Pengalaman Keuangan Dan Tingkat Pendapatan Terhadap Perilaku Keuangan Keluarga Di Kecamatan Purwokerto Timur. Jurnal Benefit Fakultas Ekonomi dan Bisnis Universitas Muhammadiyah Purwokerto.

Robb, C. A., \& Woodyard, A. S. 2011. finanacial knowledge and best practice behaviour. Journal of financial Counseling and planning Volume 22 Issue 1.

Yulianti, Norma dan Silvy Meliza. 2013. Sikap Pengelola Keuangan Dan Perilaku Perencanaan Investasi Keluarga Di Surabaya. Journal of Business and Banking Vol. 3 No 1, Mei 